\title{
REKONSTRUKSI FIQH PENDARAHAN PERVAGINAM DENGAN PENDEKATAN MEDIS
}

\author{
Nur Lailatul Musyafa'ah \\ Institut Agama Islam Negeri Sunan Ampel Surabaya, Indonesia \\ E-mail: shafadesign@yahoo.com
}

\begin{abstract}
This article discusses the reconstruction of figh (Islamic jurisprudence) with regard to vaginal bleeding using a medical approach. The fiqh of vaginal bleeding discusses menstruation, postpartum, and istibâdah. The discussion of fiqh is normative in nature, as it is based on the Qur'ân and Hadith. Technological developments in medical science affect the deconstruction of fiqh pertaining to vaginal bleeding. As a resut, the opinions of previous jurists become less relevant, and the figh of vaginal bleeding needs to be reconstructed accordingly. This reconstruction can be conducted by using the empirical-normative approach to the study of fiqh with regard tovaginal bleeding, redefining the fiqh of vaginal bleeding, reinterpreting the argument of figh concerning vaginal bleeding, and making medical experts as partners in determining vaginal bleeding.
\end{abstract}

Keywords: Vaginal bleeding, figh, medical approach.

\section{Pendahuluan}

Dalam fiqh, hukum yang berkaitan dengan wanita, bagaikan lautan luas tidak bertepi, ${ }^{1}$ karena itu, banyak fuqahâ' yang membahas secara khusus tentang hukum yang berkaitan dengan masalah kewanitaan di dalam kajian fiqh wanita yang disebut "fiqh al-mar'ah" atau "fiqh al-nisâ". ${ }^{3}$ Dalam pembahasan fiqh wanita, banyak dijumpai

\footnotetext{
1 Abû Muhammad Ashraf, Fatâwâ al-Mar'ah al-Muslimah, Vol. 1 (Riyad: Aḍ̂ầ alSalaf, 1996), 270.

2 Sebagai sebuah istilah, figh al-mar'ah merupakan suatu istilah yang belum dikenal dalam khazanah keilmuan klasik, namun dalam perkembangannya, banyak fuqahâ' yang mulai menulis fiqh wanita dalam karya mereka. Lihat Husein Muhammad, Islam Agama Ramab Perempuan (Cirebon: Fahmina, 2004), xxxviii.

${ }^{3}$ Di antara istilah "fiqh al-mar'ah" atau "fiqh al-nisâ", pemikir kontemporer Suriah, Muhammad Shahrûr, menyebut fiqh wanita dengan fiqh al-mar'ah daripada fiqh alnisâ'. Menurutnya, kalimat al-nisâ' merupakan jamak dari al-mar'ah, yang berarti wanita dewasa, sebagaimana penafsirannya tentang ayat waris (al-Qur'ân, 4: 11). Di
} 
permasalahan yang hukumnya diperselisihkan oleh fuqahâ', di antaranya adalah masalah perdarahan pervaginam. Masalah perdarahan pervaginam yang mencakup haid, nifas, dan istihâdah dalam fiqh memperoleh perhatian yang luar biasa dari para fuqahâ'. ${ }^{4}$ Fuqahâ' berusaha mendefinisikan dan menjelaskan hukum tentang perdarahan pervaginam, ${ }^{5}$ namun terkadang masih dijumpai kebingungan di antara para wanita yang mengalaminya, terutama yang tidak bisa membedakan jenis darahnya. Tanpa mengurangi penghargaan terhadap hasil ijtihad fuqahâ', yang telah demikian serius mencurahkan perhatiannya dalam masalah ini, dapat dikatakan bahwa sebagian besar hukum tentang perdarahan pervaginam sulit diterima mengingat ijtihad tersebut belum sepenuhnya mengakomodir kemampuan wanita dalam menerapkan hukumnya. ${ }^{6}$

Terdapat beberapa faktor yang menyebabkan rumitnya penjelasan fuqahâ' tentang hukum perdarahan pervaginam, di antaranya adalah karena keuniversalan teks al-Qur'ân dan Ḥadîth yang menjelaskan tentang hukum perdarahan pervaginam; adanya dalil yang bertentangan yang menimbulkan perbedaan pendapat di kalangan fuqahâ; dan sejarah pertumbuhan dan perkembangan wacana fiqh

ayat yang lain (al-Qur'ân, 3: 14), ia menafsirkan al-nisâ' dengan sesuatu yang datang belakangan. Lihat Muhạmmad Shahrûr, Naḥwa Ușûl Jadîdah li al-Fiqh al-Islâmî: Fiqh al-Mar'ah (Damaskus: al-Ahâlî, 2000), 255. Lihat juga Muhammad Shahrûr, al-Kitâb wa al-Qur'ân (Damaskus: al-Ahâlî, 1992), 643.

4 Badriyah Fayyumi, "Haid, Nifas, dan Istiḩậdah", dalam Amiruddin Arani (ed.), Tubuh, Seksualitas, dan Kedaulatan Perempuan (Yogyakarta: LKiS, 2002), 26.

${ }^{5}$ Sebagaimana pengertian yang dijelaskan oleh Sayyid Sâbiq tentang haid, nifas, dan istihâdah. Darah haid adalah darah yang keluar yang tidak disebabkan oleh melahirkan atau penyakit. Nifas adalah darah yang keluar akibat melahirkan atau keguguran. Darah istihậdah adalah darah yang keluar karena penyakit. Dari pengertian tersebut tidak dijelaskan lebih terinci tentang sebab terjadinya perdarahan yang keluar dari vagina. Lihat Sayyid Sâbiq, Fiqh al-Sunnah, Vol. 1 (Kairo: al-Fath li I'lâm al-'Arabî, 1996), 91-95.

${ }^{6}$ Misalnya, soal batas waktu minimal haid. Imâm al-Shâficî memberi batas minimal haid sehari semalam. Batas ini sesungguhnya tidak bermasalah jika tidak ada penjelasan yang lebih rumit dari asḥâb al-Shâfiç yang lain. Penjelasan itu adalah jika seorang wanita yang haidnya tidak lancar, ia haid lebih dari satu hari, tetapi ketika dirinci waktu keluarnya haid tidak sampai sehari semalam, maka keadaan yang demikian tidak bisa dikatakan haid. Konsekuensinya ia harus meng-qad̂a' seluruh salat yang ditinggalkan. Lihat Fayyumi, "Haid, Nifas, dan Istị̂âdah", 28.

${ }^{7}$ Seperti hukum darah yang keluar pada masa hamil, sebagian fuqahâ' berpendapat bahwa darah tersebut adalah darah haid dan yang lain berpendapat bahwa darah 
(yakni abad kedua Hijriyah) memang sangat jauh dari campur tangan wanita. Hampir sebagian besar teks keagamaan, khususnya literatur fiqh, banyak didominasi oleh pihak lelaki, sehingga terdapat beberapa produk fiqh wanita yang kurang menampung aspirasi wanita. ${ }^{8}$

Perkembangan zaman dan kemajuan teknologi berpengaruh kepada perkembangan medis ${ }^{9}$ serta berimplikasi pada produk fiqh wanita, di antaranya fiqh perdarahan pervaginam. ${ }^{10}$ Kemajuan dalam bidang endokrinologi bertambah pesat setelah diketahuinya poros hipotalamus-hipofisis-ovarium, ${ }^{11}$ seperti ditemukannya pengobatan hormonal yang berpengaruh pada siklus haid. ${ }^{12}$

Kitab fiqh perdarahan pervaginam yang ditulis fuqahâ' belakangan, banyak yang merujuk kepada kitab fiqh klasik, tanpa diimbangi analisis kritis terhadap pemahaman di dalamnya. Padahal setelah Islam berkembang luas dan melampaui kurun waktu tertentu, masyarakat sudah berubah dan dengan demikian, terdapat beberapa ajaran fiqh yang dianggap kurang relevan untuk dipraktikkan. ${ }^{13}$ Seperti cara membedakan antara darah istihâdah dan darah haid adalah dengan

tersebut adalah darah istihâạah. Lihat Ibn Rushd, Bidâyat al-Mujtahid wa Nihâyat alMuqtasid (Surabaya: al-Hidâyah, t.th.), 38.

${ }^{8}$ Pada dasarnya, yang lebih memahami problematika wanita adalah wanita sendiri, termasuk aspirasi yang harus tertuang dalam ketentuan fiqh, karena itu, betapa pentingnya fuqahâ' wanita lebih aktif lagi dalam memasuki wacana keagamaan. Lihat Jamhari, Citra Perempuan dalam Islam Pandangan Ormas Keagamaan (Jakarta: Gramedia, 2003), 49.

9 Menurut M. Anwar, dalam beberapa dekade terakhir ini, telah terjadi kemajuan teknologi yang luar biasa yang juga berdampak pada praktik kedokteran. Ilmu kedokteran menjadi super spesialis, dan para dokter menjadi semakin berorientasi pada teknologi. Perubahan tersebut harus diimbangi dengan pendekatan multidisipliner, termasuk di dalamnya ilmu sosial. Lihat M. Anwar, "Perkembangan Teknologi Rekayasa Reproduksi Manusia dalam Rangka Penanganan Problema Infertilitas", Majalah Obstetri, dan Ginekologi Indonesia, Vol. 21, No. 4 (Oktober 1997), 194.

10 Misalnya, timbulnya perdarahan bercak pada akseptor implant. Lihat Rizani Amran, George Adrian, dan Hariyadi Manan, "Perdarahan Bercak pada Akseptor Implant", Majalab Obstetri dan Ginekologi Indonesia, Vol. 21, No. 4 (Oktober 1997), 220-223.

11 Julianto Witjaksono, T. Zulkifli Jacoeb, H. Enud Jaja Surjana, "Penyakit Ovarium Polikistik", Majalah Obstetri dan Ginekologi Indonesia, Vol. 9, No. 3 (Juli 1983), 163.

12 Achmad Satori Ismail, "Fiqih Perempuan, dan Feminisme", dalam Mansour Fakih (ed.), Membincang Feminisme (Surabaya: Risalah Gusti, 1996), 149.

13 Mansour Fakih, Analisis Gender dan Transformasi Sosial (Yogyakarta: Pustaka Pelajar, 2007), 4-5. 
melihat warna darah, jika darahnya hitam berarti itu darah haid. Penjelasan darah haid dengan melihat warna darah, kurang relevan secara medis, karena darah yang keluar dari vagina kemungkinan sudah tercampur dengan cairan dari vagina atau serviks, atau darah tersebut tidak berasal dari uterus (rahim).

Perdarahan pervaginam perlu dikaji lebih komprehensif, baik dalam perspektif medis maupun fiqh. ${ }^{14}$ Pendekatan medis dalam menjelaskan sebab terjadinya perdarahan pervaginam sangat diperlukan, untuk mengetahui jenis darah yang keluar dari kemaluan seorang wanita, sedangkan fiqh merupakan sekumpulan hukum sharî̀ yang berhubungan dengan amaliah yang dihasilkan dari istinbât hukum melalui ijtihad. ${ }^{15}$ Selama ini, kajian tentang ilmu medis dan fiqh tentang perdarahan pervaginam seperti tersekat oleh suatu penghalang, padahal keduanya pernah berkembang pesat pada awal perkembangan agama Islam, yang melahirkan penemuan besar yang bermanfaat bagi peradaban manusia. ${ }^{16}$

Dalam sejarah Islam, ilmu medis pernah mengalami zaman keemasannya di antara perkembangan berbagai macam keilmuan lainnya, seperti ilmu agama, bahasa, fisika, ilmu alam, arsitektur, dan geografi. Kitab tentang medis dari Arab, merupakan salah satu bahan yang banyak diterjemahkan dan dijadikan rujukan dalam dunia medis di Eropa. Perkembangan ilmu medis dalam Islam mencapai masa puncaknya pada zaman Hârûn al-Rashîd (685 M) yang di eranya memerintahkan untuk menerjemahkan kitab medis dari Yunani, di antaranya kitab karya Galenus, Hipokrates, dan lain sebagainya. Dari proses terjemahan tersebut, muncul pakar medis dari kalangan Muslim, di antaranya al-Râzî (850-932M), ${ }^{17}$ Ibn Sînâ (980-1037M) ${ }^{18}$, Abû al-Qâsim al-Zahrâwî (936-1013), ${ }^{19}$ dan Ibn Rushd (1126-1198). ${ }^{20}$

\footnotetext{
14 Beberapa dampak positif dari kemajuan teknologi dalam bidang obstetri, dan ginekologi adalah diagnosa pasien dapat ditegakkan lebih dini, lebih cepat, lebih tepat, dan dapat mendeteksi kelainan yang sebelumnya tidak dapat diketahui memakai pemeriksaan konvensional. Lihat R. Prajitno Prabowo, "Dampak Kemajuan Teknologi pada Bidang Obstetri, dan Ginekologi", Majalah Obstetri dan Ginekologi Indonesia, Vol. 17, No. 3 (Juli 1991), 153-157.

15 Ismail, "Fiqih Perempuan", 149.

16 Aḥmad Muhammad Kan'ân, al-Mawsî́ah al-Tibbîyah al-Fiqhîyah (Beirut: Dâr alNafâis, 2007), 19.

17 al-Râzî bertugas sebagai dokter di Baghdad selama lebih dari 50 tahun. Ia menulis tentang demam tinggi yang mengakibatkan campak, dan cacar, penyakit anak, dan cara mengobati demam dengan mengompresnya dengan air dingin, dan
} 
Perkembangan medis dalam Islam juga berpengaruh pada ilmu fiqh. Dalam beberapa kitab fiqh, terdapat beberapa fuqahâ' yang tidak segan mengutip pendapat pakar medis untuk melengkapi argumen mereka, sebagaimana yang dilakukan Ibn Rushd, ia mengutip pendapat Galenus dan Hiprokrates dalam men-tarìth hukum tentang wanita yang mengalami perdarahan waktu hamil, apakah itu termasuk darah haid atau istihâdah. Menurut Ibn Rushd, ada dua hal yang memengaruhi darah wanita hamil: pertama, darah yang dilihat wanita hamil adalah darah haid, jika kondisi wanita tersebut kuat dan janinnya kecil, sebagaimana pendapat Hipokrates dan Galenus. Kedua, bisa jadi darah yang keluar dari wanita hamil adalah darah istihâadah, jika janin lemah karena mengikuti kondisi ibunya yang lemah dan sakit. ${ }^{21}$ Selain itu, terdapat pendapat dalam mazhab Hanbalî bahwa wanita hamil tidak haid, hal tersebut dikarenakan darah tersebut tidak keluar, karena menjadi makanan bayi dan ketika melahirkan darah tersebut berubah menjadi susu. ${ }^{22}$

Penjelasan fiqh tersebut kurang relevan dengan penemuan medis yang terakhir, meskipun demikian banyak fuqahâ' belakangan yang masih mengutip penjelasan tersebut dalam karya fiqh mereka, di antaranya; al-'Uthaymin, ${ }^{23}$ 'Abd al-Wahhâb al-Sha'rânî' ${ }^{24}$ dan 'Abd al-

menggunakan bijâmah (bekam) untuk mengobati stroke. Lihat Gustav Lobon, Hạâarat al-'Arab (Kairo: Maktabat al-Usrah, 2000), 488.

${ }^{18}$ Ibn Sînâ menulis al-Qânûn fî al-Ṭibb, kitab tersebut menjadi sumber rujukan utama dalam ilmu medis di Eropa. Ibid., 490.

${ }^{19}$ Ia adalah Abû al-Qâsim Khalâf b. al-'Abbâs al-Zahrâwî. Abû al-Qâsim lahir di Zahrâ’, yang terletak di sekitar Kordoba, Spanyol, karena itu dia dikenal dengan nama "al- Zahrâwî". Di Barat ia dikenal sebagai Abulcasis, ia adalah dokter kerajaan pada masa Khalifah al-Ḥakam II dari Dinasti Umayyah. Karya terkenalnya adalah alTasrif, kumpulan praktik kedokteran yang terdiri atas 30 volume. Dalam buku tersebut dibahas tentang ilmu bedah, alat, dan cara bedah. Lihat Isma'il al-Faruqi, dan Lois Lamya al-Faruqi, Atlas Budaya Islam (Bandung: Mizan, 1998), 359.

20 Ibn Rushd (1126-1188) adalah seorang filsuf dari Spanyol (Andalusia). Dia mendalami banyak ilmu, seperti kedokteran, hukum, matematika, dan filsafat. Dalam ilmu medis, ia mentafsirkan kitab Ibn Sînâ, kitab tentang pengobatan, kitab tentang racun dan demam. Lihat Lobon, Hậârat al' 'Arab, 492.

${ }^{21}$ Ibn Rushd, Bidâyat al-Mujtahid, Vol. 1, 51.

22 Shams al-Dîn Abî al-Farj 'Abd al-Raḥmân b. Abî 'Umar Muhammad b. Aḥmad b. Qudâmah, al-Sharḥ al-Kabîr, Vol. 1 (Beirut: Dâr al-Kitâb al-'Arabî, t.th.), 313.

23 'Uthaymin menjelaskan tentang hikmah dari adanya haid adalah janin di dalam perut ibunya tidak mungkin mendapat makanan dari luar perut, sedangkan ibunya tidak mungkin mensuplai makanan kepadanya. Oleh karena itu, Allah menciptakan 
'Azîz Muhammad al-Salmân. ${ }^{25}$ Hal tersebut menunjukkan perlu ada penelitian lebih lanjut tentang fiqh perdarahan pervaginam dengan pendekatan medis yang aktual, tidak hanya mengutip pada karya fuqahâ' terdahulu, tetapi juga diimbangi dengan hasil penelitian pakar medis masa kini.

Berdasarkan latar belakang tersebut, penulis tertarik untuk membahas tentang rekonstruksi fiqh perdarahan pervaginam dengan pendekatan medis.

\section{Pendekatan Medis dalam Fiqh Perdarahan Pervaginam}

Perdarahan pervaginam dalam perspektif medis dibahas dalam ilmu obstetri dan ginekologi. Perkataan obstetric berasal dari obsto (Bahasa Latin) yang berarti mendampingi. ${ }^{26}$ Dalam bahasa Inggris, obstetrix, diartikan sebagai midwife. Kalimat tersebut berasal dari kata mid yang berarti with (bersama) dan kata wife yang berarti woman (wanita). ${ }^{27}$ Menurut Sarwono Prawirohardjo, kata "obstetric" atau "obstetrix" dalam bahasa Latin berkaitan dengan "obstare", yang berarti berdiri di sampingnya, dalam hal ini berdiri di samping wanita yang sedang bersalin, tetapi keterangan ini tidak diterima oleh semua pihak. Pendapat lain menyebutkan bahwa kata aslinya adalah "abstetrix" yang berarti membantu seseorang yang sedang bersalin. Dari beberapa arti kata tersebut, Sarwono mendefinisikan obstetri

darah bagi kaum wanita untuk bisa dijadikan suplai makanan bagi janin di dalam perut seorang ibu, tanpa perlu mengunyah, dan mencernanya melalui pusar, meresap ke dalam pembuluh darah, dan tersuplai sebagai makanan untuk janin. Muhammad b. Ṣâlih al-'Uthaymin, Majmû' Fatâwâ wa Rasâil Ibn 'Uthaymin (Mekkah: Dâr al-Wațan, 1413 H), 222.

24 'Abd al-Wahhâb al-Sha'rânî mengatakan bahwa sebab keluarnya darah dari orang hamil adalah karena lemahnya janin disebabkan ia menyantap darah haid. Umumnya, bayi tidak mengalami kelemahan kecuali bila ia lahir di bulan genap, dan ia menjadi kuat bila lahir di bulan ganjil, karenanya, ada bayi yang lahir pada bulan ketujuh bisa hidup, namun yang lahir pada bulan kedelapan tidak bertahan hidup. Lihat 'Abd al-Wahhâb al-Sha'rânî dalam Muhammad Nûruddîn Marbû Banjar alMakkî, al-Ị̣âtah bi Ahamm Masâil al-Ḥayd wa al-Nifâs wa al-Istiḥ̂ạah (Kairo: Ihyyâ' alKutub al-Turâth al-Islâmî, 1993).

25 'Abd al-'Azîz Muhammad al-Salmân, al-As'ilah wa al-Ajwibah al-Sharîyah, Vol. 1 (CD al-Maktabah al-Shâmilah), 57.

${ }^{26}$ Bagian Obstetri, dan Ginekologi Fakultas Kedokteran Universitas Padjadjaran, Obstetri Fisiologi (Bandung: Eleman, 1983), 3.

27 Petraglia, "Society for Gynecologic Investigation", dalam F. Gary Cunningham, et al., 23rd Edition Williams Obstetrics (New York: McGraw-Hill, 2010), 2. 
sebagai ilmu kedokteran yang khusus mempelajari segala soal yang bersangkutan dengan lahirnya bayi. ${ }^{28}$

Dalam kamus Oxford, dijelaskan bahwa obstetri adalah cabang dari ilmu kedokteran yang berkaitan dengan kelahiran bayi, perawatan dan pengobatan ibu, sebelum dan sesudah melahirkan. ${ }^{29}$ Dalam Kamus Kebidanan, disebutkan bahwa obstetri adalah cabang ilmu kedokteran yang membahas mengenai perawatan wanita selama kehamilan, kelahiran, dan puerperium (nifas). ${ }^{30}$ Dengan demikian, yang menjadi objek ilmu ini adalah kehamilan, persalinan, nifas, dan bayi yang baru dilahirkan.

Ginekologi berasal dari kata Yunani gynecos, yang berarti wanita. Ginekologi adalah cabang ilmu kedokteran yang mengobati penyakit pada wanita, khususnya kondisi organ reproduksi dan genitalia. ${ }^{31}$ Pengetahuan tentang ginekologi meliputi gangguan haid, perdarahan uterus abnormal, keputihan, endometriosis, penyakit radang panggul, bartolinitis, mioma uteri, tumor ovarium neoplastik jinak, infertilitas, menopause, dan berbagai penyakit kandungan lainnya.

Menurut Petraglia, praktik kebidanan telah ada pada zaman Mesir kuno dan kerajaan Romawi. ${ }^{32}$ Dari catatan kertas papirus (1900-1550 SM) yang ditemukan, diketahui bahwa praktik kebidanan telah dikenal di Mesir sebagai pekerjaan wanita yang menangani masalah obstetri dan ginekologi, khususnya dalam menangani proses kelahiran. Lebih lanjut Petraglia menjelaskan bahwa pelayanan kebidanan telah ada semenjak abad pertengahan hingga abad ke 18 Masehi, ketika tugas ahli bedah mulai digantikan oleh bidan. Hal tersebut menandakan bahwa pada waktu itu proses pengobatan modern yang ilmiah mulai dianggap lebih baik bagi kesehatan ibu dan anak dibandingkan pengobatan tradisional. ${ }^{33}$

Menurut M. Jusuf Hanafiah, ginekologi mengalami perkembangan yang sangat pesat, seiring dengan kemajuan ilmu pengetahuan dan teknologi. Dalam tiga dasawarsa terakhir, telah terjadi perkembangan yang pesat, antara lain oleh kemajuan endokrinologi reproduksi, pemeriksaan ultrasonografi, teknologi reproduksi buatan, dan lainnya.

28 Sarwono Prawirohardjo, Ilmu Kebidanan (Jakarta: PT. Bina Pustaka Sarwono Prawirohardjo, 2009), 3.

29 Petraglia, "Society for Gynecologic", 2.

${ }^{30}$ Nicola V. Winson, Kamus Kebidanan Bergambar (Jakarta: EGC, 2008), 294.

${ }^{31}$ Ibid., 177.

32 Petraglia, "Society for Gynecologic", 2.

${ }^{33}$ Ibid. 
Aspek etik, hukum, agama, dan sosial perlu mendapat perhatian dalam menerapkan ilmu pengetahuan dan teknologi kedokteran mutakhir, sehingga benar-benar berlandaskan iman, takwa, etikolegal, serta falsafah dan budaya bangsa. ${ }^{34}$

\section{Konstruksi Fiqh Perdarahan Pervaginam}

Fiqh perdarahan pervaginam berkaitan erat dengan pembahasan tentang haid, nifas, dan istihâdah. Dalam pembahasan perdarahan pervaginam, fuqahâ' sering berbeda pendapat tentang warna dan bentuk darah haid, ${ }^{35}$ usia menarke, ${ }^{36}$ usia menopause, ${ }^{37}$ siklus haid ${ }^{38}$

34 M. Jusuf Hanafiah, "Ginekologi di Indonesia dari Masa ke Masa”, Majalah Obstetri,
dan Ginekologi Indonesia, Vol. 23, No. 4 (Oktober 1999), 185 .
${ }^{35}$ Dalam mazhab Hanafî dikatakan bahwa warna darah haid ada enam, yaitu: hitam,
merah, keruh, hijau, dan turbîyah (seperti warna debu), dan kuning. Mazhab al-Shâfíî
menglasifikasikan warna darah haid berdasarkan urutan kekuatannya, yaitu: hitam,
merah, oranye, kuning, dan keruh. Selain warna, mazhab Shâfîi mencirikan darah
haid dengan kental, berbau, kental sekaligus berbau, tidak kental, dan tidak berbau.
Menurut mazhab Hanbalî, warna darah haid adalah hitam, merah, dan keruh atau
kuning. Menurut mazhab Mâlikî, warna darah haid ada tiga, yaitu: merah, kuning,
dan keruh (antara hitam dan putih). 36 Usia menarke dalam Mazhab Hanafî adalah sembilan tahun, karena Nabi menikahi 'Âishah ketika usianya sembilan tahun, dan didapati riwayat bahwa terdapat seorang perempuan, putri dari Abî Muṭ̂ি‘, yang telah memiliki cucu pada usia 19 tahun. Di riwayat Hanafî yang lain, usia menarke dibatasi tujuh tahun, didasarkan pada hadîth Nabi murûhum bi al-salậ idhâ balaghû sab'an. Darah yang keluar sebelum usia menarke disebut darah fasâd (rusak). Menurut mazhab Hanafî, al-Shâfîî, dan Mâlikî, usia menarke adalah 9 tahun Hijriyah. Mazhab Hanafî didasarkan pada Hadîth 'Âishah yang diriwayatkan oleh Ibn 'Umar idhâ balaghat aljâriyah tis'a sinîn fahiya imra'ah. Pendapat al-Shâfi'î didasarkan pada hasil penemuan alShâfîî bahwa perempuan Tihâmah telah mengalami haid pada usia 9 tahun. Hal tersebut berdasarkan penemuan al-Shâfîî terhadap seorang perempuan San'â Yaman yang sudah memiliki cucu pada usia 21 tahun. Lihat Yahyâ b. Muhammad al-Shaybânî, Ikhtilâf al-Aimmah al-'Ulamâ', Vol. 1 (Beirut: Dâr al-Kutub al-'Ilmîyah, 2002), 73.

${ }^{37}$ Mazhab Shâfi î̀, dan Hanafî menyatakan bahwa tidak ada batas usia menopause. Menurut mazhab Mâlikî, usia menopause adalah 70 tahun. Di dalam Mazhab Hanbalî terdapat tiga pendapat mengenai usia menopause, yaitu: 1) usia menopause adalah 50 tahun, namun jika setelah usia tersebut terjadi perdarahan yang berulang, maka ia masih dalam masa usia haid, 2) usia menopause adalah 60 tahun, dan 3) usia menopause perempuan Arab 60 tahun, dan perempuan non-Arab 50 tahun. Pandangan Hanbalî ini didasarkan pada hạâth yang diriwayatkan 'Âishah idhâ balaghat khamsîn sanah kharajtu min ḥad al-ḥaỵ, dan lan tarâ al-mar'ah fî batnihâ waladan ba'da al-khamsinn. Lihat 'Abd al-Rahmân al-Jazîrî, Kitâb al-Fiqh 'alâ al-Madhâhib alArba'ah, Vol. 1 (Beirut: Dâr al-Kutub al-'Ilmîyah, 1990), 115. 
(masa suci dan masa haid), masa nifas (masa minimal nifas ${ }^{39}$ dan masa maksimal nifas ${ }^{49}$, bentuk darah istihâạah, masa istị̂ậdah, ${ }^{41}$ dan implikasi hukum dari perdarahan pervaginam.

Penelitian fiqh perdarahan pervaginam bersifat normatif, karena penelitian tersebut berangkat dari teks yang sudah tertulis dalam kitab

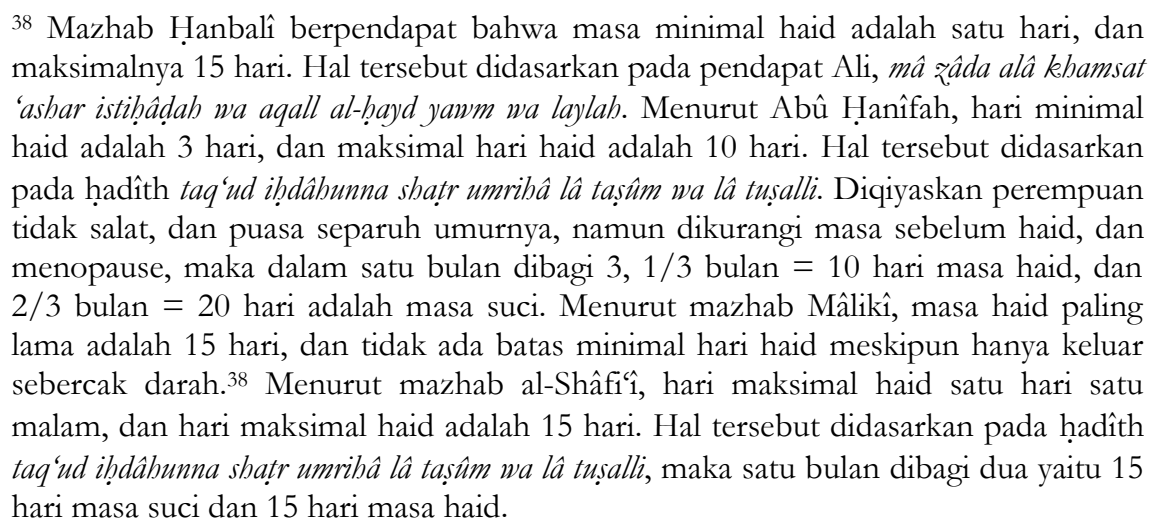

39 Menurut mazhab al-Shâfîî, Mâlik, dan Ibn Taymîyah, tidak ada batas minimal masa nifas. Menurut Zayd b. 'Alî, masa minimal nifas perempuan melahirkan dihitung tiga kali masa haid; jika haidnya lima hari, masa nifasnya adalah lima dikalikan tiga berarti 15 hari. Menurut Abû Yûsuf, minimal masa nifas ibu melahirkan adalah 11 hari sama dengan masa maksimal waktu haid (10 hari) kemudian ditambah satu hari untuk membedakannya. Menurut Abû Hanîfah, 25 hari, menurut al-Hasan al-Bașrî, 20 hari, ${ }^{39}$ dan menurut al-Thawrî, minimal nifas tiga hari. Lihat Muhammad b. 'Alî b. Muhammad al-Shawkânî, Nayl al-Awtâr (Kairo: Dâr al-Hadîth, 1998), 359; dan Ibn Rushd, Bidâyat al-Mujtabid, Vol. 1, 51.

${ }^{40}$ Fuqahâ' berselisih tentang masa maksimal nifas. Menurut mazhab Imâm Mâlik, Aḥmad b. Hanbal, 'Uthaymin, dan al-Sha'râwî, masa nifas maksimal adalah 40 hari. Menurut mazhab al-Shâfíî, dalam salah satu riwayatnya, masa maksimal nifas adalah 70 hari. Menurut Abû Hanîfah, dan dalam salah satu riwayat al-Shâfîî, dan Imam Mâlik, masa maksimal nifas adalah 60 hari, dan menurut Hasan al-Bașrî, masa nifas adalah 50 hari. Lihat al-Shawkânî, Nayl al-Awtâr, Vol. 3, 358; dan al-Jazîrî, Kitâb alFigh, Vol. 1, 107.

41 Menurut Imâm Mâlik, secara umum, perempuan istihâạah tidak haid kecuali dengan tiga syarat: 1) perempuan itu bisa membedakan jenis darahnya, 2) darah istihâdah berubah sifatnya ke darah haid, dan 3) darah istihâdah berubah menjadi darah haid setelah melampaui masa minimal suci, yaitu 15 hari. Dalam mazhab Imâm Aḥmad terdapat empat riwayat tentang hitungan haid pada masa istiḥadah: 1) haidnya dihitung masa minimal haid, 2) haidnya dihitung enam sampai tujuh hari karena itu merupakan kebiasaan mayoritas perempuan, 3) haidnya dihitung pada masa maksimal haid, 4) haidnya dihitung sesuai kebiasaan perempuan tersebut. Lihat al-Shaybânî, Ikhtilâf al-Aimmah, 75. 
suci, ${ }^{42}$ yaitu al-Qur'ân dan Hadîth. Di antara sumber hukum tersebut terdapat dalil yang bertentangan, sehingga bisa menimbulkan penafsiran dan pemahaman yang berbeda. Hampir dalam semua pembahasan mengenai haid, nifas dan istiḩâdah terdapat perbedaan pendapat, karena itu ia termasuk wilayah ijtihad, dan perselisihan merupakan hal yang wajar dalam pembahasan fiqh. Dalam merujuk sumber hukum Islam yang bertentangan tersebut, dalam usûl al-figh terdapat konsep ta'ârud al-adillah. Secara etimologis, ta'ârud berarti taqâbul dan tamattu' atau bertentangan dan sulitnya pertemuan, sedangkan al-adillab berarti alasan, argumen atau dalil.

Dengan demikian, ta'ârud al-adillah adalah pertentangan antara dalil yang satu dengan dalil yang lain. ${ }^{43}$ Berdasarkan konsep ta'ârud aladillah, fuqahâ' berusaha mencari solusi hukum dari dalil tersebut dengan al-jam' wa al-tawfíq, al-naskh, atau al-tarjìh. Contoh dari al-jam'wa al-tawfíq dalam masalah perdarahan pervaginam adalah cara menghitung masa istibâdah. Terdapat dua Hadith yang bertentangan mengenai hal tersebut, Hadith Hamnah yang meriwayatkan bahwa masa haidnya dihitung enam sampai tujuh hari, dan Hadîth Fâtimah bint Abû Hubaysh yang menghitung masa haidnya dengan melihat warna darah haid yaitu hitam yang diketahui. Dari dua dalil tersebut fuqahâ' berusaha menafsirkannya dengan metode al-jam' wa al-tawfíq, bahwa jika ia bisa membedakan darahnya, maka masa haidnya adalah sesuai darah haid yang keluar, sedangkan apabila ia tidak bisa membedakan darahnya, maka dihitung sebagaimana kebiasaan wanita haid yaitu lamanya enam sampai tujuh hari. ${ }^{44}$

\section{Dekonstruksi Fiqh Perdarahan Pervaginam}

Pembahasan perdarahan pervaginam dalam perspektif medis bersifat empiris dan berimplikasi pada wilayah sosial, sehingga ia berbeda dengan pembahasan fiqh perdarahan pervaginam yang bersifat normatif dan berimplikasi pada wilayah hukum ibadah. Pendekatan medis yang empiris tersebut bisa mendekonstruksi perumusan fiqh perdarahan pervaginam yang bersifat normatif. ${ }^{45}$

\footnotetext{
42 M. Amin Abdullah, Studi Islam: Normativitas atau Historisitas? (Yogyakarta: Pustaka Pelajar, 2002), vi.

${ }^{43}$ Wahbah al-Zuhaylî, al-Wajî̀ fî Usûul al-Fiqh (Beirut: Dâr al-Fikr al-Mu'âṣir, 1995), 243.

${ }^{44}$ Wahbah al-Zuhaylî, al-Fiqh al-Islamî wa Adillatuh (Beirut: Dâr al-Fikr, 1997), 482.

45 Perdarahan pervaginam dalam medis dibahas di dalam ilmu obstetric, dan ginekologi, yang bersifat empiris. Ciri dari pendekatan empiris bertujuan
} 
Pembahasan perdarahan pervaginam dalam perspektif medis di antaranya berkaitan dengan fisiologi, patologi, dan etiologi. Dalam penelitian medis yang bersifat empiris, cara menentukan perdarahan pervaginam adalah dengan diadakan pemeriksaan, baik dengan cara manual atau lainnya, untuk mengetahui jenis perdarahan tersebut. Dalam pemeriksaan terhadap pasien, dilakukan dengan beberapa diagnosis, di antaranya melalui pertanyaan riwayat haid pasien, laboratorium, pemeriksaan dengan USG (ultra sonografi), baik melalui uterus maupun vagina, vaginal toucher, atau spekulum.

Di antara pendekatan medis dalam penentuan darah yang mendekonstruksi fiqh perdarahan pervaginam adalah penentuan perdarahan pervaginam yang ditinjau dari warna dan bentuknya. Penentuan tersebut dianggap kurang objektif, karena keakuratannya diragukan. Hal tersebut disebabkan darah yang keluar dari vagina kemungkinan sudah tercampur oleh cairan dari serviks atau vagina, atau darah tersebut tidak berasal dari luruhnya endometrium, karena itu penentuan perdarahan pervaginam tidak bisa hanya dilihat melalui warna dan bentuk darah, tetapi untuk memastikannya diperlukan pemeriksaan.

Penentuan usia menarke dalam mazhab fiqh adalah sembilan tahun Hijriyah, penentuan tersebut tidak bisa dijadikan landasan secara umum, karena wanita kemungkinan bisa mengalami menarke pada usia delapan tahun. Untuk menentukan perdarahan haid, harus dilakukan pemeriksaan, begitu juga dalam penentuan usia menopause.

Fuqahâ' berselisih dalam menentukan siklus haid, yang terdiri dari masa suci dan masa haid. Secara medis, siklus haid dilihat dari siklus endometrium dan ovarium, yang keduanya memiliki beberapa fase. Siklus ovarium terdiri dari fase folikuler, ovulasi, dan luteal. Siklus endometrium terdiri dari fase proliferasi, sekresi, implantasi, dan menstruasi. Kedua siklus tersebut memiliki ciri khas tersendiri.

Pendekatan medis juga mendekonstruksi pemahaman fuqahâ' tentang perdarahan pada masa kehamilan. Dari pendekatan medis diketahui bahwa wanita hamil tidak haid, jika terjadi perdarahan, menandakan adanya gangguan dalam kehamilan tersebut, yaitu bisa

mempelajari keteraturan, dan keterangan yang terdapat dalam alam semesta, seperti ilmu anatomi, fisika, ilmu pasti, kedokteran, kimia, dan geologi. Lihat Sudigdo Sastroasmoro, Dasar-dasar Metodologi Penelitian Klinis (Jakarta: Binarupa Aksara, 1995), 1. 
dikarenakan adanya tanda abortus, kehamilan ektopik, atau kelainan letak plasenta.

Dari pendekatan medis bisa diketahui sebagian besar penyakit yang mengganggu organ genital wanita, sehingga bisa menyebabkan terjadinya perdarahan. Pembagian fuqahâ' mengenai wanita istihẩdah bisa dijelaskan dengan sebab terjadinya perdarahan abnormal dalam perspektif medis, di antaranya perdarahan abnormal yang disebabkan kelainan hormonal maupun non-hormonal.

Dalam penjelasan mengenai hukum yang ditimbulkan dari perdarahan pervaginam, pendekatan medis lebih berorientasi kepada kesehatan wanita. Selama perbuatan tersebut tidak membahayakan kesehatan wanita, tidak ada larangan untuk melakukannya. Hal tersebut berbeda dengan perdarahan pervaginam dalam perspektif fiqh yang berimplikasi kepada beberapa larangan dalam beribadah.

\section{Rekonstruksi Fiqh Perdarahan Pervaginam}

Pendekatan medis bisa mendekonstruksi fiqh perdarahan pervaginam, karena itu diperlukan rekonstruksi fiqh perdarahan pervaginam yang sesuai dengan maslahat sharî‘ ah dan perkembangan medis. Di antara rekonstruksi tersebut adalah dengan menjadikan pendekatan empiris-normatif sebagai pendekatan dalam pembahasan fiqh perdarahan pervaginam, redefinisi perdarahan pervaginam, reinterpretasi dalil yang berkaitan dengan perdarahan pervaginam, dan menjadikan pakar medis sebagai mitra dalam ijtihad fiqh perdarahan pervaginam.

1. Pendekatan Empiris-normatif dalam Perumusan Figh Perdarahan Pervaginam

Perumusan fiqh perdarahan pervaginam perlu dilakukan dengan pendekatan empiris-normatif, guna mendapatkan hasil ijtihad hukum yang maksimal. Dengan demikian, pesan ilahi mampu direalisasikan sesuai tuntutan umat sesuai dengan masa dan tempat, karena itu, pendekatan kombinasi empiris-normatif merupakan model pendekatan yang perlu dikembangkan dalam kajian ușull al-figh masa kini dan yang akan datang. ${ }^{46}$

Dalam sejarahnya, fuqahâ' empat mazhab sebenarnya telah menggabungkan metode empiris-normatif ini, misalnya dalam penentuan usia menarke dan menopause, namun dalam perkembangannya terjadi sakralisasi kitab fiqh, sehingga pandangan

46 Ibid., 194. 
mereka tentang usia haid tersebut dijadikan sebagai landasan hukum dalam fiqh perdarahan pervaginam.

Dalam kajian fiqh perdarahan pervaginam, kombinasi antara model empiris-normatif, terutama bagi seorang fakih merupakan satu keniscayaan, karena perdebatan seputar perdarahan pervaginam dalam fiqh tidak bisa didekati secara normatif saja, tetapi juga harus berdasarkan pada penelitian empiris.

Dari pendekatan empiris-normatif dalam perdarahan pervaginam, dapat diketahui bahwa antara tinjauan medis dan fiqh tentang perdarahan pervaginam saling berkaitan. Dengan pendekatan medis dapat diketahui sebab perdarahan pervaginam yang dialami para wanita, dengan demikian, seorang wanita bisa mengenali jenis perdarahan yang dialaminya, sedangkan fiqh bertujuan untuk menentukan hukum dari suatu permasalahan. Pendekatan medis bisa dijadikan alat bantu seseorang untuk mengetahui sebab perdarahan, sehingga bisa diambil kesimpulan hukum yang paling sesuai, asalkan tidak bertentangan dengan naș. Dengan pendekatan empiris-normatif tersebut, diharapkan terjadi istinbât hukum yang tidak bertentangan dengan maqâsid al-sharîah khususnya hif ž al-nafs, yang berarti menjaga kesehatan.

Pendekatan tersebut bisa jadi berimplikasi kepada perubahan hukum yang ada, seperti hubungan suami istri saat istri istihâadah. Fuqahâ' bersepakat, kecuali Imâm Aḥmad, bahwa jimak saat istri istị̂ậah diperbolehkan, karena didasarkan pada Hadîth yang diriwayatkan 'Ikrimah, bahwa Umm Habîbah istiḩậdah dan suaminya menggaulinya saat istihâdah, dan Rasulullah tidak menentangnya. Dari pendekatan medis diketahui bahwa darah merupakan tempat yang baik untuk kuman, jika darah yang normal saja yaitu haid dianjurkan untuk tidak melakukan hubungan seksual, apalagi jika perdarahan akibat penyakit. Dikhawatirkan dengan hubungan tersebut dapat memperparah kondisi istri atau menular kepada suami. Dengan kedua pendekatan tersebut tentunya menguatkan pendapat Aḥmad yang melarang hubungan suami istri saat istri istihâadah.

2. Redefinisi Fiqh Perdarahan Pervaginam

Para fuqahâ' telah berijtihad merumuskan fiqh perdarahan pervaginam, namun seiring dengan perkembangan medis, perumusan tersebut lebih didasarkan pada pandangan fuqahâ' beberapa abad silam, sehingga kurang sesuai dengan perkembangan teknologi yang berpengaruh pada perkembangan medis. Untuk itu diperlukan 
redefinisi tentang perdarahan pervaginam, disesuaikan dengan ilat, sebab, atau hikmah hukum.

Fuqahâ' mendefinisikan haid sebagai perdarahan normal dari uterus wanita yang sehat, bukan karena penyakit dan bukan karena melahirkan. Definisi haid tersebut sebenarnya tidak bertentangan dengan definisi ilmu medis, tetapi kurang spesifik sehingga perlu disesuaikan dengan perkembangan medis saat ini, bahwa haid adalah perdarahan secara periodik dan siklik dari uterus, disertai pelepasan (deskuamasi) endometrium. ${ }^{47}$

Selain definisi haid, perlu dijelaskan juga tentang fisiologi haid. Haid yang normal adalah haid yang ovulatoir, bahwa haid tersebut dipengaruhi oleh hubungan hipotalamus, hipofisis, dan ovarium (bypothalamic-pituitary-ovarian axis). Menurut teori neurohormonal yang dianut sekarang, hipotalamus mengawasi sekresi hormon gonadotropin oleh adenohipofisis melalui sekresi neohormon yang disalurkan ke sel adenohipofisis lewat sirkulasi portal yang khusus. Hipotalamus menghasilkan faktor yang telah diisolasi dan disebut Gonadotropin Releasing Hormone ( $\mathrm{Gn} \mathrm{RH})$, karena dapat merangsang pelepasan Luteinizing Hormone (LH) dan Follicle Stimulating Hormone (FSH) dari hipofisis. ${ }^{48}$

Dalam mendefinisikan nifas, fuqahâ' sepakat bahwa nifas merupakan perdarahan yang diakibatkan persalinan, dan mereka berselisih tentang hukum perdarahan yang terjadi sebelum persalinan dan saat persalinan berlangsung. Secara medis, nifas adalah perdarahan setelah lahirnya plasenta sampai dengan enam minggu (42 hari). ${ }^{49}$ Ia adalah proses kembalinya organ wanita setelah melahirkan ke bentuk sebelum kehamilan. Batasan melahirkan adalah ketika janin lahir pada usia 20 minggu lebih, atau beratnya telah mencapai 500

\footnotetext{
47 Muhammad Yusuf Hanifiah, "Haid, dan Siklusnya", dalam Hanifa Wiknjosastro (ed.), Ilmu Kandungan (Jakarta: Yayasan Bina Pustaka Sarwono Prawirohardjo, 2007), 103.

48 Ibid., 104.

${ }^{49}$ R. Soerja Hadijono, "Asuhan Nifas Normal”, dalam Abdul Bari Saifuddin, Ilmu Kebidanan Sarwono Prawirohardjo (Jakarta: Yayasan Bina Pustaka Sarwono Prawirohardjo, 2009), 356.
} 
gram atau lebih, ${ }^{50}$ jika kurang dari itu, maka ia disebut abortus, dan tidak nifas. ${ }^{51}$

Dari definisi tentang haid dan nifas, diketahui bahwa istihâdah atau perdarahan pervaginam abnormal adalah perdarahan bukan haid dan bukan nifas. Definisi tersebut sama dengan penjelasan fuqahâ', namun dengan pendekatan medis dapat diketahui sebab dari terjadinya perdarahan yaitu bisa disebabkan oleh kelainan hormonal dan kelainan non-hormonal. Kelainan hormonal disebabkan oleh siklus yang anovulatoir, atau dikarenakan penggunaan obat $\mathrm{KB}$, sedangkan kelainan non-hormonal bisa disebabkan oleh infeksi, kanker, atau perdarahan akibat kehamilan (abortus, kehamilan ektopik, dan kelainan trofoblas, dan kelainan lainnya).

Penjelasan tersebut penting dilakukan, karena batasan istibâdah dalam fiqh ditentukan berdasarkan warna dan hari, sehingga kurang spesifik dan sulit diterapkan. Dengan diketahui sebab perdarahan, dapat memudahkan kaum wanita untuk menentukan jenis perdarahannya.

3. Reinterpretasi Dalil Fiqh Perdarahan Pervaginam

Reinterpretasi perlu dilakukan dalam memahami fiqh perdarahan pervaginam, baik yang tertulis dalam al-Qur'ân, Hadîth, atau kitab fiqh, di antaranya adalah reinterpretasi teks al-Qur'ân, Hadîth, dan reinterpretasi dalil tentang implikasi hukum bagi wanita haid, nifas, dan istihâadah.

a. Reinterpretasi kalimat al-adhâ dalam al-Qur'ân, 2: 222:

Dalam menjelaskan tentang haid, Allah berfirman dalam alQur'ân, 2: 222, yang menyatakan bahawa haid adalah adhâ: Dalam terjemah al-Qur'ân yang diterbitkan Kementerian Agama, kalimat adhâ diartikan dengan sesuatu yang kotor. ${ }^{52}$ Menurut A. Qodri Azizy, arti kata tersebut kurang relevan karena berimplikasi negatif. Padahal kalimat adbâ memiliki beberapa arti. Menurutnya, arti yang paling

50 Bantuk Hadijanto, "Perdarahan pada Kehamilan Muda", dalam Abdul Bari Saifuddin, Ilmu Kebidanan Sarwono Prawirohardjo Jakarta: Yayasan Bina Pustaka Sarwono Prawirohardjo, 2009), 460.

51 Perdarahan akibat abortus termasuk istihâdah, karena ia merupakan gangguan kehamilan bukan persalinan.

52 Penafsiran al-Qur'ân yang dilakukan Kementerian Agama telah mengalami beberapa revisi, pada penafsiran sebelumnya adhâ diartikan dengan kotoran. Kemudian pada tahun 2000 kata adhâ direvisi dengan sesuatu yang kotor. Dalam terjemahan bahasa Inggris kalimat adhâ diartikan dengan burt (luka), dan pollution (kotor). Lihat The Holy Qur'an (Saudi Arabia: King Fahd Holy Qur'an, t.th.), 95. 
sesuai adalah penyakit, karena ketika haid, wanita akan merasa sakit jika dipaksa berhubungan seks. ${ }^{53}$

Berbeda dengan A. Qodri Azizy, A. Hassan, mengartikan adhâ dengan kemadharatan. Diartikan kemadharatan, karena bercampur dengan mereka di tempat yang terkutuk bagi menanam benih, serta dengan maksud supaya terpelihara daripada zina, dan supaya dapat anak saleh. ${ }^{54}$

Penterjemahan Kementerian Agama di atas, ${ }^{55}$ didasarkan pada penafsiran para mufassir yang ada dalam karya mereka. Di antara kitab tafsir yang dijadikan rujukan penterjemahan Kementerian Agama adalah kitab Tafsîr Ayât al-Aḥkâm karya Muhammad 'Alî Sâbûnî, yang mengartikan kalimat adhâ dengan ma yu'dhî bih min makrûh (sesuatu yang dibenci). Kalimat al-mahị̂d dikatakan adhâ karena darah haid itu qadhar (kotor), najis, dan natin (busuk). ${ }^{56}$ Penafsiran tersebut juga terdapat dalam kitab tafsir lainnya. ${ }^{57}$

Dalam kamus Lisân al-'Arab, al-adhâ diartikan dengan kull mâ ta'adhdhayta bib (segala sesuatu yang melukaimu), selain itu terkadang ia diartikan al-mawj (gelombang). ${ }^{58}$ Dalam al-Munjid, adhâ diartikan dengan al-darar al-yasîr (bahaya yang kecil). ${ }^{59}$

Dalam kamus al-Mawrid, kalimat adhâ memiliki beberapa arti, yaitu harm (bahaya), demage (rusak), injury (cedera), burt (sakit/luka), wrong (salah), detriment (rugi), lesion (luka), grievance (keluhan), evil (jahat), nuisance (gangguan), annoyance (jengkel), trouble (masalah), dan barassment

53 A. Qodri Azizy, "Upaya Rekonstruksi Wacana Islam tentang Seksualitas", dalam Irwan Abdullah (ed.), Islam, dan Konstruksi Seksualitas (Yogyakarta: Pustaka Pelajar, 2002), 220.

54 A. Hassan, Tafsir Alquran (t.t.: t.p., 1962), 119.

55 Menurut Muchlis Hanafi, terjemah al-Qur'ân yang dilakukan Kemenag sejak tahun 1965 hingga 2011 telah mengalami revisi sebanyak dua kali. Revisi pertama dilakukan pada tahun 1989, yakni penyempurnaan redaksional yang dianggap sudah tidak relevan dengan perkembangan bahasa. Revisi kedua dilakukan antara tahun 1998 hingga 2002, yakni penyempurnaan secara menyeluruh yang mencakup aspek bahasa, konsistensi pilihan kata, substansi, dan aspek transliterasi. Lihat Tim Redaksi, "Polemik Terjemah al-Qur'ân", Hidayatullah, Edisi 8, XXIV (Desember 2011), 25.

${ }^{56}$ Muhammad 'Alî al-Ṣâbûnî, Tafsîr Âyât al-Aḥkâm (Beirut: Dâr al-Kutub al-'Tlmîyah, t.th.), 207.

57 Muhammad 'Alî al-Sâyis, Tafsîr Âyât al-Aḥkâm (Beirut: Dâr al-Kutub al-'Ilmîyah, 1998), 135.

${ }^{58}$ Ibn Manzûr, Lisân al-Arab, Vol. 1 (Kairo: Dâr al-Ma'ârif, t.th.), 54.

${ }^{59}$ Louis Ma'lûf, al-Munjid (Beirut: Dâr al-Mashriq, 1986), 6. 
(gangguan). ${ }^{60}$ Dari kamus tersebut, tidak ada pemaknaan kalimat adhâ dengan kotor.

Dari beberapa arti di atas, menurut penulis kalimat adhâ lebih mendekati arti luka. Luka tersebut berasal dari terlepasnya endometrium dari uterus, sehingga terjadi perdarahan. Luka tersebut bukan menandakan wanita haid sedang sakit, tetapi malah menandakan wanita tersebut dalam keadaan sehat dan tidak sakit, ${ }^{61}$ Karena haid merupakan tanda dari kesehatan telur dan uterus yang berlanjut dan tanda dari lancarnya fungsi hormon seks. ${ }^{62}$

Dengan reinterpretasi terhadap arti adbâ yang bukan sesuatu yang kotor, tetapi berarti luka, ayat tersebut menunjukkan bahwa al-Qur'ân tidak bertentangan dengan ilmu, dan tidak menyudutkan posisi wanita sebagai orang yang kotor atau sakit.

b. Reinterpretasi Ayat tentang Iddah dalam al-Qur'ân, 65:4

Perdarahan pervaginam dalam fiqh berimplikasi pada penghitungan masa 'iddah, sebagaimana dijelaskan pada QS. 65:4.

Dan wanita yang tidak haid lagi (monopause) di antara istrimu, jika kamu ragu (tentang masa 'iddah-nya), maka masa 'iddah mereka adalah tiga bulan; dan begitu (pula) wanita yang tidak haid, dan wanita yang hamil, waktu 'iddah mereka itu ialah sampai mereka melahirkan kandungannya, dan barangsiapa yang bertakwa kepada Allah, niscaya Allah menjadikan baginya kemudahan dalam urusannya. ${ }^{63}$

${ }^{60}$ Rûhî Ba'albaki, al-Mawrid (Beirut: Dâr al-'Ilm li al-Malâyîn, 1993), 67.

61 Terdapat mitos bahwa wanita yang haid berarti ia sedang sakit. Mitos tersebut justru tidak benar karena justru sebaliknya, haid adalah proses alami yang dialami oleh setiap wanita produktif. Haid berarti menandakan bahwa wanita tersebut dalam kondisi sehat, dan sistem reproduksinya bekerja dengan normal sebagaimana mestinya. Lihat Daru Wijayanti, Fakta Penting Seputar Kesehatan Reproduksi Wanita (Yogyakarta: Book Marks, 2009), 19.

${ }^{62}$ Haid sebagai suatu peristiwa biologis bukanlah persoalan jika tidak menyangkut dua proses penting secara sosial: pertama, jika haid tidak mengalami pemitosan yang berlangsung melalui proses konstruksi yang panjang, di mana agama menjadi sumber inspirasi, dan legitimasi penting di dalamnya yang disebabkan oleh interpretasi teks yang bias gender, dan kedua, bukan menjadi persoalan jika peristiwa biologis yang dimitoskan itu tidak merugikan kaum wanita dalam kehidupan sosialnya. Berbagai fakta menunjukkan sebaliknya, justru peristiwa biologis yang normal itu memiliki implikasi yang luas untuk terjadinya berbagai proses sosial yang merugikan wanita yang dipengaruhi oleh pemitosan yang berlangsung dalam masyarakat. Oleh karena itu, mitos tersebut sesungguhnya merupakan ruang yang kondusif bagi terjadinya kekerasan terhadap wanita secara simbolis. Lihat ibid., 4.

${ }^{63}$ Departemen Agama RI, Mushaf al-Qur'ân Terjemah, 559. 
Para fuqahâ' sepakat bahwa ayat tersebut menjelaskan tentang masa 'iddah bagi wanita yang tidak haid, baik karena masih kecil ${ }^{64}$ atau karena menopause, bahwa iddah mereka adalah tiga bulan. ${ }^{65}$ Selain itu dijelaskan pula masa 'iddah bagi wanita hamil, yang masa 'iddah-nya akan selesai dengan melahirkan. Kesepakatan tersebut berdasarkan pada sebab turunnya ayat al-Qur'ân, 65:4 bahwa setelah turun ayat alQur'ân, 2:228, tentang 'iddah bagi wanita yang ditalak suaminya ${ }^{66}$ dan ayat al-Qur'ân, 2:231, yang menjelaskan tentang 'iddah bagi wanita yang ditinggal mati oleh suaminya ${ }^{67}$, Ubay b. Ka'b berkata kepada Rasulullah: "Wahai Rasul, terdapat beberapa kondisi wanita yang belum tersebut dalam ayat tersebut", Rasul bertanya: "Siapa mereka?", Ubay menjawab: "Anak-anak, wanita tua, dan wanita hamil", maka turunlah ayat keempat dari surat al-Ṭalâq tersebut.

Dari ayat tersebut, fuqahâ' berselisih pendapat tentang 'iddah bagi wanita yang mengalami menopause $\operatorname{dini}^{68}$, 'iddah wanita yang

64 Bagi wanita yang belum mencapai umur sembilan tahun, fuqahâ' berbeda pendapat. Fuqahâ' Hanafí mewajibkan 'iddah bagi wanita tersebut meskipun masih kecil, sedangkan fuqahâ' Mâlikî, dan al-Shâfíî tidak mewajibkan 'iddah bagi wanita yang masih kecil yang belum mampu berhubungan badan, dan mewajibkan 'iddah jika ia telah mampu berhubungan badan, meskipun belum mencapai umur 9 tahun. Fuqahâ' Hạabalî, dan Imâmîyah tidak mewajibkan 'iddah bagi wanita yang belum genap berusia 9 tahun, meskipun mampu melakukan hubungan badan. Lihat Muhammad Isna Wahyudi, Fiqh Iddah Klasik, dan Kontemporer (Yogyakarta: LKiS, 2009), 93.

${ }^{65}$ Su'âd Ibrâhîm Șâlih, Aḍ̂â' 'alâ Nižâm al-Usrah fî al-Islâm (Zaitun: Dâ al-Dịâ', 1996), 189.

66 'Iddah-nya adalah tiga qurù'.

67 'Iddah-nya adalah empat bulan sepuluh hari.

68 Fuqahâ' berbeda pendapat mengenai seorang wanita yang masih muda, namun sudah tidak mengalami haid. Dalam hal ini harus dijelaskan apakah berhentinya haid tersebut dikarenakan ia hamil atau tidak, jika tidak hamil, maka Imâm Mâlik, Aḥmad, dan Ishâaq berpendapat bahwa masa 'iddah-hnya adalah satu tahun berdasarkan hitungan dari 9 bulan ('iddah wanita hamil) ditambah tiga bulan ('iddah wanita yang tidak haid). Hitungan tersebut juga berlaku bagi wanita yang setelah dicerai dia mengalami haid satu kali atau dua kali, kemudian haidnya berhenti, maka masa 'iddah-nya ditambah satu tahun lagi. Menurut Hanafî, ‘iddah-nya tetap dihitung tiga kali haid, meskipun ia haid dua puluh tahun kemudian, sampai ia benar-benar memasuki masa menopouse, maka 'iddah-nya dihitung tiga bulan. Wanita tersebut termasuk murtâbah (dalam kondisi ragu antara masa reproduksi atau menopause). Lihat Muḥammad b. Aḥmad b. Abî Bakr al-Qurțubî, Jâmi al-Aḥkâm al-Fighîyah, Vol. 2 (Beirût: Dâr al-Kutub al-'Ilmîyah, t.th.), 359-360. 
mengalami keguguran ${ }^{69}$, 'iddah bagi wanita yang tidak lancar haidnya ${ }^{70}$, atau 'iddah wanita yang mengalami istihâa $d a b{ }^{71}$ dan 'iddah wanita yang masih kecil. ${ }^{72}$

Ayat al-Qur'ân, 65:4 tersebut perlu dikaji ulang maknanya. Ayat tersebut menyebutkan 'iddah wanita yang tidak haid secara berurutan adalah 'iddah wanita menopause, 'iddah wanita yang belum haid, dan 'iddah wanita yang hamil. Dengan pendekatan medis, urutan ayat tersebut mengandung hikmah, di antaranya:

Pertama, penyifatan kalimat "in irtabtum" (jika kalian ragu) dalam wanita menopause, sesuai dengan penelitian medis tentang wanita menopause bahwa sebelum menopause terdapat fase perimenopause, yang biasanya ditandai dengan siklus haid yang tidak teratur. Wanita

${ }^{69}$ Menurut mazhab Mâlikî, wanita yang mengalami keguguran sama dengan wanita yang melahirkan, karena itu, 'iddah-nya selesai dengan terjadinya keguguran. Hal tersebut berdasarkan pada al-Qur'ân, 65: 4 bahwa ayat tersebut menerangkan tentang kondisi ibu hamil yang melahirkan secara umum, meskipun melahirkan janin yang masih berbentuk 'alaqah atau mudghah, karena keduanya sudah merupakan bagian dari pembentukan anak. Mazhab al-Shâfi'î berpendapat bahwa keguguran yang dianggap sebagai iddah wanita hamil adalah jika janin sudah berbentuk manusia. Perbedaan pendapat tersebut didasarkan pada kelayakan janin bisa hidup di dunia atau belum, karena usia anak yang dikatakan mampu hidup di dunia adalah setelah kehamilan enam bulan sebagaimana firman Allah dalam al-Qur'ân, 46: 15 bahwa masa mengandung, dan menyusui adalah 30 bulan. Menyusui dua tahun sama dengan 24 bulan sisanya enam bulan adalah masa minimal kehamilan. Lihat AlQurțubî, Jâmi' al-Aḥkâm, 363-364. Lihat juga 'Abd al-Karîm Dayyâb, dan Aḥmad Qurquz, Ma'a al-Tibb fì al-Qur'ân al-Karim (Damaskus: Muassasat 'Ulûm al-Qur'ân, t.th.), 25.

${ }^{70}$ Bagi wanita yang tidak lancar haidnya, baik karena penyakit atau bukan, maka masa iddah-nya adalah satu tahun. Seperti pada wanita yang ditalak setelah melahirkan kemudian menyusui, sehingga ia tidak lancar haidnya atau tidak mengalami haid dalam beberapa waktu. Imâm Mâlik berpendapat bahwa masa iddah-nya adalah sepanjang waktu sampai ia haid, maka kemudian dihitung 3 kali haid atau sampai usia menopause, maka selanjutnya "iddah-nya berubah menjadi tiga bulan. Lihat Al-Qurțubî, Jâmi' al-Aḅkâm, 360.

${ }^{71}$ Menurut Ibn al-Musayyab, dan al-Layth, 'iddah wanita istihâdah yang dicerai suami atau ditinggal mati suaminya adalah satu tahun, meskipun wanita tersebut mengetahui jenis darah, dan hari haidnya di antara masa istihâạah-nya. Menurut alShâfîî, 'iddah wanita istị̂ậah adalah tiga bulan. Menurut Ibn 'Umar, jika wanita tersebut mengenali jenis darah, dan mengetahui masa haid di antara masa istihâadahnya, maka 'iddah-nya dihitung tiga qurû'. Lihat ibid., 361.

72 Jika wanita tersebut belum pernah haid, maka iddah-nya 3 bulan, namun jika dalam masa 'iddah-nya dia mengalami haid, maka iddah-nya berubah menjadi tiga qurû. Lihat ibid., 360-364. 
dianggap menopause, ketika haidnya minimal telah terhenti selama satu tahun. Dari penafsiran dengan pendekatan medis tersebut, 'iddah tiga bulan tidak hanya berlaku bagi wanita menopause saja, tetapi juga berlaku bagi wanita perimenopause. ${ }^{73}$

Kedua, penyebutan "wa al-lâî lam yahị̣na" (dan wanita yang tidak haid) setelah penjelasan menopause. Urutan tersebut mengandung hikmah bahwa kalimat tersebut berlaku bagi semua wanita yang belum haid setelah bercerai, baik karena masih kecil atau karena hal lain. ${ }^{74}$ Secara rasional, seharusnya penyebutan ayat ini lebih dahulu daripada penyebutan wanita menopause, tetapi ternyata terkandung hikmah dari maksud urutan tersebut bahwa secara medis, wanita tidak haid (amenorea) dibagi menjadi dua, yaitu amenorea primer (wanita yang belum pernah haid) ${ }^{75}$ dan amenorea sekunder (wanita yang pernah haid, tetapi terhenti haidnya). Dari pendekatan tersebut, perlu penafsiran ulang bahwa wanita yang dicerai suaminya kemudian tidak haid, hendaknya menunggu sampai tiga bulan. Hal tersebut berbeda dengan pandangan fuqahâ' selama ini, yang hanya membatasi kalimat "wa al-lâî lam yahị̣na" (dan wanita yang tidak haid) tersebut pada "iddah wanita yang masih kecil, yang belum pernah haid sama sekali.

Ketiga, urutan ketiga dari ayat ini adalah "wa ulât al-ạ̣mâl ajalahunn an yaḍa'n hamlahunn" (dan wanita hamil hendaknya menunggu masa 'iddah mereka hingga melahirkan kandungannya). Hikmah yang terkandung dari urutan tersebut adalah dari pendekatan medis diketahui bahwa di antara sebab wanita tidak haid ${ }^{76}$ adalah adanya kehamilan, dan kehamilan biasanya dapat diketahui dengan pasti ketika usia janin memasuki umur tiga bulan. ${ }^{77}$ Ketika seorang wanita yang dicerai dipastikan hamil, maka 'iddah-nya dihitung sampai melahirkan.

73 Iddah tiga bulan tersebut sesuai dengan haid tiga kali bagi mayoritas wanita.

${ }^{74}$ Dalam menafsirkan ayat ini, mufassir bersepakat bahwa wanita yang dimaksud dalam ayat tersebut adalah wanita yang belum pernah haid. Lihat al-Ṣabûnî, Tafsîr Âyât al-Ạkâm, 444.

75 Wanita yang mengalami amenorea primer, diharapkan memeriksakan dirinya ketika usia 16-18 tahun tidak mengalami haid, karena terdapat kemungkinan adanya kelainan organ reproduksinya, misalnya karena tiadanya lubang pada himen, sehingga menghalangi keluarnya darah haid, atau karena kelainan kromoson bahwa ia tampil cantik tetapi memiliki gen laki-laki.

${ }_{76}$ Baik pada amenorea primer maupun sekunder.

77 Meskipun saat ini terdapat alat medis yang bisa mengetahui adanya kehamilan sejak dini, tetapi secara manual, biasanya seorang ibu merasa yakin hamil setelah tiga-empat bulan. 
Selain itu, kalimat yang digunakan tentang 'iddab yang habis dengan melahirkan adalah "an yada'n hamlahunn" (melahirkan kandungan) dan tidak menggunakan "yalidna" (melahirkan). Dari pendekatan medis diketahui, bahwa kehamilan terjadi semenjak bertemunya sel sperma dengan sel telur dan berlangsung hingga melahirkan. Kehilangan kehamilan bisa terjadi kapanpun selama masa kehamilan, baik karena abortus, kelahiran prematur, atau kelahiran cukup umur. Berdasarkan hal tersebut 'iddah wanita yang mengalami abortus kompletus adalah sama dengan 'iddah wanita hamil yang melahirkan.

Dari penjelasan di atas diketahui bahwa iddah wanita perimenopause dan wanita yang pernah haid, namun terhenti haidnya bukan karena kehamilan, masa iddah-nya adalah tiga bulan. Hal tersebut berbeda dengan pandangan fuqahâ' selama ini, yang mayoritas berpendapat untuk menunggu sembilan bulan ('iddah wanita hamil) atau menunggu satu tahun (gabungan antara iddah wanita hamil, sembilan bulan, dengan 'iddah wanita yang tidak haid, tiga bulan), atau bahkan menunggu sampai haid lagi.

Penjelasan tersebut menandakan bahwa ayat al-Qur'ân, 65:4 tersebut menyempurnakan masa iddah wanita yang belum tercakup dalam ayat al-Qur'ân, 2:228 dan ayat al-Qur'ân, 2:231. Ayat al-Qur'ân 65:4 mencakup iddah wanita menopause, perimenopause, post menopause, amenorea primer, amenorea sekunder, wanita istihâdah, dan wanita hamil dengan kelahiran atau abortus kompletus.

c. Reinterpretasi kalimat 'irq dalam Hadîth Nabi

Dalam menjelaskan istihâdah, Nabi menjelaskan bahwa itu adalah irq sebagaimana disebutkan dalam Hadîth yang diriwayatkan Fâtimah bint Abû Hubaysh bahwa ia sedang istihâdah, Rasulullah saw berkata kepadanya, bahwa darah haid adalah berwarna hitam yang dikenal, jika demikian tinggalkanlah salat namun jika selainnya, maka berwudu dan salatlah karena itu adalah 'irq. ${ }^{78}$

Hadith tersebut menjelaskan bahwa istihâdah adalah irq. Dalam literatur kitab fiqh dijelaskan bahwa 'irq adalah perdarahan yang terjadi pada uterus (rahim) paling bawah yang disebut 'âdbil. Untuk itu dalam penjelasan fuqahâ' disebutkan bahwa haid adalah perdarahan yang

78 al-Shawkânî, Nayl al-Awtâr, 337. 
terjadi pada uterus bagian atas, jika terjadi perdarahan pada uterus bagian bawah, maka itu adalah istihâdah. ${ }^{79}$

Dalam kamus al-Mawrid dijelaskan bahwa 'irq memiliki beberapa arti, di antaranya vein, blood vessel (pembuluh darah), race (keturunan), stock (stok), descent (asal mula), dan rib (tulang). ${ }^{80}$ Berdasarkan beberapa arti tersebut, arti yang paling sesuai untuk irq adalah pembuluh darah, karena secara umum perdarahan terjadi akibat pecahnya pembuluh darah.

Berdasarkan hal tersebut, pendekatan medis menguatkan sabda Rasulullah bahwa istihâdah adalah 'irq (perdarahan yang diakibatkan pecahnya pembuluh darah). Pembuluh darah tersebut tidak hanya ada di uterus bagian bawah, tetapi pada setiap anggota badan manusia. Berkaitan dengan istihâdah, irq adalah perdarahan abnormal, perdarahan tersebut bisa berasal dari uterus atau organ genital lainnya.

d. Reinterpretasi Hadîth tentang Penentuan Perdarahan Pervaginam dengan Melihat Warna Darah

Penentuan darah haid, berdasarkan warna, bentuk, dan bau, merupakan hal yang bisa dilakukan bagi seorang wanita yang mengalami perdarahan, tetapi hal tersebut kurang objektif, karena unsur darah dalam tubuh manusia adalah sama, apalagi ketika darah tersebut diketahui setelah keluar dari vagina. Bagi wanita awam, ia mungkin tidak mengetahui apakah darah tersebut berasal dari uterus atau alat genitalia lainnya, karena itu diperlukan pemeriksaan dalam, bagi wanita yang mengalami perdarahan abnormal. Penentuan darah berdasarkan warna berdasarkan pada Hadîth yang diriwayatkan dari Fạtimah bint Abî Hubaish bahwa ia sedang istihâadah, Rasulullah saw berkata kepadanya: "Darah haid adalah berwarna hitam yang dikenal, jika demikian tinggalkanlah salat namun jika selainnya, maka berwudu dan salatlah karena itu adalah "irq".

Selain itu terdapat Hadith yang diriwayatkan 'Alqamah yang meriwayatkan dari ibunya bahwa para wanita mengutus seseorang untuk menghadap 'Âishah dengan membawa sobekan kain yang terdapat kapas berisi cairan kuning (dari darah haid). 'Âishah pun berkata "Janganlah kalian tergesa-gesa menyudahi (menganggap haid telah selesai) sampai kalian melihat warna putih bersih".

${ }^{79}$ al-Shawkânî, Nayl al-Awtâr, 337; Qalyûbî, dan 'Umayrah, Qalyûbî wa 'Umayrah, Vol. 1 (Kairo: Dâr Ihyyầ' al-Kutub al-'Arabîyah, 1918), 98; dan Wahbah al-Zuhaylî, al-Fiqh al-Islâmî, 478.

${ }^{80}$ Ba'albakî, al-Mawrid, 758. 
Penentuan darah haid dengan melihat warnanya yaitu hitam, kuning, atau keruh, bisa dilakukan ketika hal tersebut belum ditemukan cara mengetahui darah haid secara ilmiah. Dari penelitian ilmu medis dapat diketahui bahwa darah haid yang keluar melalui vagina, telah terkontaminasi oleh cairan atau bakteri dari serviks dan vagina, sehingga terkadang sulit diketahui apakah darah tersebut berasal dari uterus, serviks, atau dari vagina.

Pemeriksaan medis, dapat memastikan sebab keluarnya perdarahan pervaginam, dan hal tersebut lebih objektif daripada menilai darah haid, nifas, dan istihâdah dengan hanya melihat warna darah. Berdasarkan hal tersebut, diperlukan reinterpretasi terhadap teks yang hanya mendeteksi darah haid melalui warnanya, apalagi Rasulullah bersabda dam aswad yu'raf (darah hitam yang diketahui). Menurut Sayyid Sâbiq, kalimat dam aswad yu'raf berarti darah hitam yang sesuai dengan kebiasaan haid wanita. ${ }^{81}$ Penyifatan warna hitam dengan kalimat yu'raf perlu dikaji lebih lanjut.

e. Reinterpretasi Hadîth tentang Hukum Wanita Istihâadah

Istihâadah adalah perdarahan bukan haid dan bukan nifas, ia disebabkan oleh adanya kelainan hormonal maupun non-hormonal. Fuqahâ' sepakat bahwa istihậ̂ah dihukumi sebagaimana wanita yang suci, sehingga ia tidak terhalang untuk melaksanakan ibadah. Di bawah ini dijelaskan analisis Hadîth tentang istiḩâdah.

Pertama, Hadith yang diriwayatkan oleh 'Urwah b. al-Zubayr:

Dari 'Urwah b. al-Zubayr dari 'Âishah, istri Rasulullah saw. bahwa Ummu Habîbah bint Jaḥsh istri 'Abd al-Raḥmân b. 'Awf mengadu kepada Rasulullah tentang darah, Rasulullah saw. bersabda: "Tahanlah (haidmu) selama hitungan haidmu kemudian mandilah", maka ia mandi setiap kali hendak salat".

Kedua, Hadîth riwayat Hamnah bint Jaḥsh yang berbunyi:

Dari Ḥamnah bint Jaḥsh meriwayatkan bahwa Rasulullah saw bersabda tentang istihâdah: "Itu adalah dorongan setan. Hitunglah masa haidmu enam sampai tujuh hari, lalu mandilah dan salatlah. Bila telah bersih, salatlah 23 atau 24 hari, dan puasalah, karena itu sudah mencukupimu. Demikian pula, kerjakan setiap bulan sebagaimana masa suci dan haid para wanita. Jika kamu kuat mengakhirkan Zuhur dan menyegerakan Asar, maka kamu mandi dan menjamak salat Zuhur dan Asar, kemudian kamu akhirkan magrib dan segerakan Isya' lalu mandi dan menjamak kedua salat itu, lakukanlah, dan ketika Subuh, mandi dan salatlah subuh. Kerjakanlah hal tersebut dan berpuasalah,

${ }^{81}$ Sâbiq, Fiqh al-Sunnah, 91. 
jika kamu mampu". Beliau bersabda lagi: "Ini yang paling kukagumi di antara dua perkara."

Ketiga, Hadîth yang diriwayatkan 'Âishah:

Diriwayatkan dari 'Âishah bahwa Fâtimah bint Abî Hubaysh datang kepada Rasulullah saw. dan berkata: "Sesungguhnya aku sedang istihâdah dan aku tidak bersuci, apakah aku meninggalkan salat?". Rasulullah saw. bersabda: "Sesungguhnya itu hanyalah irq (perdarahan dari pembuluh darah) dan bukan haid, tinggalkanlah salat jika datang masa haidmu, dan jika habis (masa haidmu) bersihkanlah darah tersebut dan salatlah".

Dari Hadîth tentang wanita istiḥ̂ạah di atas, terdapat penentuan haid yang perlu digarisbawahi. Pada Hadîth pertama, Umm Hạîbah bint Jaḥsh, istri 'Abd al-Raḥmân b. 'Awf, diberikan keringanan untuk meninggalkan ibadah pada masa haidnya, berdasarkan sabda Rasulullah saw "Tahanlah (haidmu) selama hitungan haidmu". Pada Hadîth yang kedua, kepada Hamnah bint Jaḥsh Rasulullah bersabda "Hitunglah masa haidmu enam sampai tujuh hari, lalu mandilah dan salatlah. Bila telah bersih, salatlah 24 atau 23 hari, puasa dan salatlah, karena itu sudah mencukupimu". Pada Hadîth yang ketiga, "Sesungguhnya itu hanyalah 'irq dan bukan haid, tinggalkanlah salat, jika datang masa haidmu dan jika habis (masa haidmu), bersihkanlah darah tersebut dan salatlah".

Ketiga Hadîth tersebut menandakan adanya hukum yang sama bagi wanita istihậdah, bahwa ia boleh meninggalkan ibadah pada masa haidnya, atau enam sampai tujuh hari setiap bulannya. Hal ini mengindikasikan bahwa wanita istihậdah tidak mutlak dihukumi sebagaimana wanita yang suci, tetapi ia bisa mendapatkan rukhsah dengan meninggalkan ibadah, pada hari kebiasaan haidnya atau selama enam sampai tujuh hari dalam sebulan.

Fuqahâ' telah berdiskusi panjang lebar mengenai wanita istiḩậdah, yang intinya adalah hukum berdasarkan Hadîth di atas berlaku bagi wanita yang telah memiliki kebiasaan haid, maka masa haidnya dihitung sesuai kebiasaannya, sedangkan bagi wanita yang tidak memiliki kebiasaan haid, maka masa haidnya dihitung selama enam sampai tujuh hari setiap bulannya. Bagi wanita yang mengetahui jenis perdarahannya, maka masa haidnya dihitung ketika ia mengetahui bahwa darah tersebut adalah darah haid, jika tidak mengetahuinya, maka darah tersebut disebut darah istihâdah.

Secara medis, wanita istiḥ̂ạah dibedakan menjadi dua, istihậ̂h yang disebabkan kelainan hormonal dan kelainan non-hormonal. 
Istihâdah yang berdasarkan kelainan hormonal bisa disebabkan oleh siklus anovulatoir (siklus haid kurang dari 25 hari atau lebih dari 35 hari), yang biasanya terjadi pada wanita menarke, pasca menarke, perimenopouse, dan pemakai obat KB. Wanita istihâadah tersebut bisa melaksanakan rukhsah, sebagaimana wanita haid, selama enam sampai tujuh hari dalam sebulan atau sesuai kebiasaan haidnya, sedangkan perdarahan uterus abnormal akibat non-hormonal atau perdarahan non-uterus, seperti perdarahan akibat kanker atau kehamilan, maka ia tidak mendapat rukhsah masa haid, tetapi ia dihukum wanita suci meskipun terjadi perdarahan.

Dengan pendekatan medis, pembagian wanita istihâdah dalam fiqh, yang terdiri dari mu'tadah, mubtadi'ah, mumayyizah, dan mutahayyirah, yang penjelasannya cukup rumit tersebut, bisa dipermudah dengan penjelasan mengenai pengetahuan kesehatan reproduksi wanita, sehingga wanita mengetahui apa yang terjadi pada dirinya dan bisa mengenali perdarahannya sehingga bisa men-tarjîh dengan mudah perdarahannya tersebut.

Selain itu, apabila wanita mengalami keraguan tentang perdarahan yang dialaminya, ia bisa memeriksakan diri ke dokter. Salah satu cara dalam penentuan darah tersebut adalah dengan sonohisterografi. Hasil penelitian Bayu Winarno dan kawannya, menunjukkan bahwa pemeriksaan sonohisterografi dapat dipergunakan untuk menilai kavum uteri dan lapisan endometrium, serta dapat mempertajam diagnostik sebelum dilakukan kuretase pada kasus perdarahan uterus. $^{82}$

Pemeriksaan perdarahan pada wanita istihâdah penting dilakukan, karena memosisikan wanita istihâdah seperti wanita yang suci, menjadikan tidak adanya perhatian khusus mengenai kesehatan wanita yang sedang istihâdah, padahal secara medis, bentuk apapun perdarahan yang abnormal, butuh penanganan dan pemeriksaan lebih lanjut, agar kesehatan wanita Muslimah dapat terjaga, apalagi jika

82 Penelitian tersebut dilakukan pada Desember 1996-April 1997. Selama waktu pengamatan, didapatkan enam kasus perdarahan uterus yang pada pemeriksaan sonohisterografi dijumpai tiga kasus dengan polip endometrium, satu kasus dengan hyperplasia, dan dua kasus menunjukkan gambaran endometrium yang normal. Kesemuanya sesuai dengan hasil pemeriksaan hispatologinya. Lihat Bayu Winarno, Azen Salim, dan Andon Hestiantoro, "Sonohisterografi pada Perdarahan Uterus", Majalah Obstetri, dan Ginekologi Indonesia, Vol. 22, No. 1 (1998), 36. 
perdarahan istihâdah tersebut bersifat ganas dan mematikan, seperti kanker, yang bisa menyebabkan kematian, jika terlambat diobati.

4. Menjadikan Pakar Medis sebagai Mitra dalam Berijtihad tentang Perdarahan Pervaginam

Ilmu medis dan fiqh memang dua hal yang berbeda. Penelitian dalam ilmu medis berkaitan dengan kesehatan, sedangkan fiqh adalah ilmu yang mempelajari tentang hukum amaliah yang berlandaskan dalil yang terperinci. Meskipun demikian, sebagai seorang Muslim, hal yang berkaitan dengan kesehatan terkadang berimplikasi pada timbulnya suatu hukum, misalnya tentang salat dan puasa bagi orang sakit atau perempuan hamil.

Dengan berkembangnya ilmu medis, diketahui tentang sebab terjadinya haid, nifas dan kelainan pada badan perempuan yang bisa menyebabkan perdarahan. Berdasarkan hal tersebut, dalam menentukan hukum perdarahan pervaginam, sudah seharusnya seorang mujtahid bekerjasama dengan pakar medis (dokter, bidan, atau ahli laboratorium), sebagaimana fuqahâ' bekerjasama dengan ahli Hadîth dalam menentukan status Hadîth.

\section{Penutup}

Perkembangan medis dalam ilmu obstetri dan ginekologi, yang berimplikasi pada timbulnya permasalahan baru, tentunya membutuhkan kajian fiqh yang lebih mendalam dengan melaksanakan ijtihad baru untuk menjawab problematika perempuan Muslimah yang berkaitan dengan kesehatan reproduksi mereka, di antaranya mengenai fiqh perdarahan pervaginam.

Perumusan fiqh perdarahan pervaginam dapat dilakukan dengan merekonstruksi fiqh perdarahan pervaginam dengan pendekatan medis yaitu dengan menjadikan pendekatan empiris-normatif dalam kajian fiqh perdarahan pervaginam, meredefinisi pengertian fiqh perdarahan pervaginam, mereinterpretasi teks fiqh perdarahan pervaginam, dan menjadikan pakar medis sebagai mitra dalam penentuan perdarahan pervaginam.

\section{Daftar Rujukan}

Abdullah, M. Amin. Studi Islam Normativitas atan Historisitas?. Yogyakarta: Pustaka Pelajar, 2002.

al-Faruqi, Isma'il, dan al-Faruqi, Lois Lamya. Atlas Budaya Islam. Bandung: Mizan, 1998. 
Amran, Rizani, Adrian, George, dan Manan, Hariyadi. "Perdarahan Bercak pada Akseptor Implant", Majalah Obstetri, dan Ginekologi Indonesia, Vol. 21, No. 4, Oktober 1997.

Anwar, M. "Perkembangan Teknologi Rekayasa Reproduksi Manusia dalam Rangka Penanganan Problema Infertilitas", Majalab Obstetri, dan Ginekologi Indonesia, Vol. 21, No. 4, Oktober 1997.

Ashraf, Abû Muḥammad. Fatâwâ al-Mar'ah al-Muslimah, Vol. 1. Riyad: Aḍ̂â' al-Salaf, 1996.

Azizy, A. Qodri. "Upaya Rekonstruksi Wacana Islam tentang Seksualitas", dalam Irwan Abdullah (ed.), Islam, dan Konstruksi Seksualitas. Yogyakarta: Pustaka Pelajar, 2002.

Ba'albakî, Rûhî. al-Mawrid. Beirut: Dâr al-'Ilm li al-Malâyîn, 1993.

Bagian Obstetri, dan Ginekologi Fakultas Kedokteran Universitas Padjadjaran. Obstetri Fisiologi. Bandung: Eleman, 1983.

Dayyâb, 'Abd al-Karîm, dan Qurquz, Aḥmad. Ma'a al-Ṭibb fì al-Qur'ân al-Karîm. Damaskus: Muassasat 'Ulûm al-Qur'ân, t.th.

Fakih, Mansour. Analisis Gender, dan Transformasi Sosial. Yogyakarta: Pustaka Pelajar, 2007.

Fayyumi, Badriyah. "Haid, Nifas, dan Istihâadah", dalam Amiruddin Arani (ed.), Tubuh, Seksualitas, dan Kedaulatan Perempuan. Yogyakarta: LKiS, 2002.

Hadijanto, Bantuk. "Perdarahan pada Kehamilan Muda", dalam Abdul Bari Saifuddin, Ilmu Kebidanan Sarwono Prawirohardjo. Jakarta: Yayasan Bina Pustaka Sarwono Prawirohardjo, 2009.

Hadijono, R. Soerja. "Asuhan Nifas Normal", dalam Abdul Bari Saifuddin, Ilmu Kebidanan Sarwono Prawirohardjo. Jakarta: Yayasan Bina Pustaka Sarwono Prawirohardjo, 2009.

Hanafiah, M. Jusuf. "Ginekologi di Indonesia dari Masa ke Masa", Majalah Obstetri, dan Ginekologi Indonesia, Vol. 23, No. 4, Oktober 1999.

Hanifiah, Muhammad Yusuf. "Haid, dan Siklusnya", dalam Hanifa Wiknjosastro (ed.), Ilmu Kandungan. Jakarta: Yayasan Bina Pustaka Sarwono Prawirohardjo, 2007.

Hassan, A. Tafsir Alquran. t.t.: t.p., 1962.

Ismail, Achmad Satori. "Fiqih Perempuan dan Feminisme", dalam

Mansour Fakih (ed.), Membincang Feminisme. Surabaya: Risalah Gusti, 1996. 
Jamhari. Citra Perempuan dalam Islam Pandangan Ormas Keagamaan. Jakarta: Gramedia, 2003.

Jazîrî (al), 'Abd al-Raḥmân. Kitâb al-Fiqh 'alâ al-Madbâhib al-Arba'ah, Vol. 1. Beirut: Dâr al-Kutub al-'Ilmîyah, 1990.

Kan‘ân, Aḥmad Muhammad. al-Mawsû́ah al-Ṭibbîyah al-Fiqhîyah. Beirut: Dâr al-Nafâis, 2007.

Lobon, Gustav. Hadârah al-'Arab. Kairo: Maktabat al-Usrah, 2000.

Ma'lûf, Louis. al-Munjid. Beirut: Dâr al-Mashriq, 1986.

Makkî (al), Muhammad Nûruddîn Marbû Banjar. al-Iḥâtah bi Ahamm Masâil al-Ḥayd wa al-Nifâs wa al-Istihâdạh. Kairo: Ihyyâ' al-Kutub alTurâth al-Islâmî, 1993.

Manzûur, Ibn. Lisân al-Arab, Vol. 1. Kairo: Dâr al-Ma'ârif, t.th.

Muhammad, Husein. Islam Agama Ramah Perempuan. Cirebon: Fahmina, 2004.

Petraglia. "Society for Gynecologic Investigation", dalam F. Gary Cunningham, et al., $23^{\text {rd }}$ Edition Williams Obstetrics. New York: McGraw-Hill, 2010.

Prabowo, R. Prajitno. "Dampak Kemajuan Teknologi pada Bidang Obstetri, dan Ginekologi", Majalah Obstetri, dan Ginekologi Indonesia, Vol. 17, No. 3, Juli 1991.

Prawirohardjo, Sarwono. Ilmu Kebidanan. Jakarta: PT. Bina Pustaka Sarwono Prawirohardjo, 2009.

Qalyûbî, dan 'Umayrah. Qalyûbî wa 'Umayrah, Vol. 1. Kairo: Dâr Ihyyâ' al-Kutub al-'Arabîyah, 1918.

Qudâmah, Shams al-Dîn Abî al-Farj 'Abd al-Raḥmân b. Abî 'Umar Muhammad b. Aḥmad Ibn. al-Sharh al-Kabîr, Vol. 1. Beirut: Dâr al-Kitâb al-'Arabî, t.th.

Qurțbî (al), Muhammad b. Aḥmad b. Abî Bakr. Jâmi al-Aḥkâm alFiqhîah, Vol. 2. Beirût: Dâr al-Kutub al-'Ilmîyah, t.th.

Redaksi, Tim. "Polemik Terjemah al-Qur'ân", Hidayatullah, Edisi 8, XXIV, Desember 2011.

Rushd, Ibn. Bidâyat al-Mujtahid wa Nibâyat al-Muqtasid. Surabaya: alHidâyah, t.th.

Ṣâbûnî (al), Muhammad 'Alî. Tafsîr Âyât al-Aḅkâm. Beirut: Dâr alKutub al-'Ilmîyah, t.th. 
Șâlih, Su'âd Ibrâhîm. Adwwâ' 'alâ Nizââm al-Usrah fî al-Islâm. Zaitun: Dâr al-Diyâ', 1996.

Sâyis (al), 'Alî Muḥammad. Tafsî̀ Âyât al-Aḅkâm. Beirut: Dâr al-Kutub al-'Ilmîyah, 1998.

Sâbiq, Sayyid. Fiqh al-Sunnah, Vol. 1. Kairo: al-Fatḥ li I'lâm al-'Arabî, 1996.

Salmân (al), 'Abd al-'Azîz Muhammad. al-As'ilah wa al-Ajwibah alSharîyah, Vol. 1. CD al-Maktabah al-Shâmilah.

Sastroasmoro, Sudigdo. Dasar-dasar Metodologi Penelitian Klinis. Jakarta: Binarupa Aksara, 1995.

Shahrûr, Muhammad. al-Kitâb wa al-Qur'ân. Damaskus: al-Ahâlî, 1992.

-----. Nahwwa Usû́l Jadîdah li al-Fiqh al-Islâmî: Fiqh al-Mar'ah. Damaskus: al-Ahâlî, 2000.

Shawkânî (al), Muhammad b. 'Alî b. Muhammad. Nayl al-Awtâr, Vol. 1. Kairo: Dâr al-Hạdîth, 1998.

Shaybânî (al), Yahyâ b. Muhammad. Ikhtilâf al-Aimmah al-Ulamâ', Vol. 1. Beirut: Dâr al-Kutub al-'Ilmîyah, 2002.

The Holy Qur'an. Saudi Arabia: King Fahd Holy Qur'an, t.th.

'Uthaymin (al), Muhammad b. Ṣalih.̣. Majmû' Fatâwâ wa Rasâil Ibn Uthaymin. Mekkah: Dâr al-Wațan, 1413 H.

Wahyudi, Muhammad Isna. Fiqh Tddah Klasik, dan Kontemporer. Yogyakarta: LKiS, 2009.

Wijayanti, Daru. Fakta Penting Seputar Kesehatan Reproduksi Wanita. Yogyakarta: Book Marks, 2009.

Winarno, Bayu, Salim, Azen, dan Hestiantoro, Andon. "Sonohisterografi pada Perdarahan Uterus", Majalah Obstetri, dan Ginekologi Indonesia, Vol. 22, No. 1, 1998.

Winson, Nicola V. Kamus Kebidanan Bergambar. Jakarta: EGC, 2008.

Witjaksono, Julianto, Jacoeb, T. Zulkifli, Surjana, H. Enud Jaja. "Penyakit Ovarium Polikistik", Majalah Obstetri, dan Ginekologi Indonesia, Vol. 9, No. 3, Juli 1983.

Zuhaylî (al), Wahbah. al-Fiqh al-Islamî wa Adillatuh. Beirut: Dâr al-Fikr, 1997.

----- al-Wajî̀ fî Usûul al-Fiqh. Beirut: Dâr al-Fikr al-Mu'âṣir, 1995. 